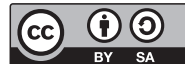

DOI https://doi.org/10.31261/IR.2021.07.07

recenzje

\title{
PAWEŁ ŁANIEWSKI
}

iD

https://orcid.org/0000-0001-9512-0942

Wymiary emigracji - Rosja, Europa, Izrael

Eretz-Israel and the Russian Émigrés in Europe: Contacts, Connections, Communications, Interactions (1919-1939)

pod redakcją Vladimira Khazana, The Hebrew University of Jerusalem, Mount Scopus, Jerusalem 2019

Następujące po rewolucji bolszewickiej i wojnie domowej fale emigracji ludności w niezwykły sposób wpłynęły nie tylko na kształt życia kulturalnego i społecznego samej Rosji oraz Europy, ale również formującej się — w znacznej mierze z emigrantów z tego regionu diaspory żydowskiej w Palestynie. „Rosja za granicą” lub "Rosja-2”, skupiająca potencjał intelektualny i kulturowy osób zmuszonych do opuszczenia kraju, w tym wielu obywateli żydowskiego pochodzenia, wymaga wnikliwej i wielopoziomowej analizy. Wciąż istnieje przy tym olbrzymi zasób wartościowych źródeł, dzięki którym możliwe staje się bliższe przyjrzenie się emigracyjnym elitom, grupującym się w okresie porewolucyjnym z jednej strony w państwach Europy Zachodniej, z drugiej w Palestynie.

Dwutomowa seria Eretz-Israel and the Russian Émigrés in Europe: Contacts, Connections, Communications, Interactions (1919-1939) pod redakcją Vladimira Khazana to niezwykle rozbudowany i skrupulatnie zredagowany zbiór dokumentów i tekstów stanowiących ciekawe studium postaw emigracji rosyjskiej w Europie i Palestynie w okresie międzywojennym. Rzuca przy tym nowe światło na kwestie natury 
kulturalnej, artystycznej, społecznej i politycznej w kręgach, które w znacznym stopniu wpływały na obraz życia społecznego i kulturalnego Rosji sowieckiej, Europy oraz formującego się Izraela. Każda z tych relacji nosi przy tym głęboko indywidualny charakter. Seria skupia się nie tylko na precyzyjnym opisaniu pierwotnego kontekstu funkcjonowania społeczności żydowskich w Rosji okresu rewolucji i wojny domowej, ale w równej mierze rozbudowanych czynników charakterystycznych dla przestrzeni, w których znalazły się mniejsze lub większe diaspory decydujące się na emigrację.

Wśród międzywojennych ruchów ludności szczególneznaczenie zyskuje emigracja lat 20. XX wieku, czyli trzecia alija (1919-1923) i czwarta alija (1924-1931). W ich wyniku w Palestynie mogła zaistnieć silna diaspora żydowska, a podwaliny pod jej sukces zarówno ekonomiczny i społeczny, jak i kulturalny — w znacznej mierze położyli emigranci z terenów rosyjskich oraz polskich. Co oczy wiste, zjawisko to samo w sobie było niejednorodne i złożone. $Z$ jednej strony istniała świadomość przynależności do narodu żydowskiego i chęć uzyskania niezależności w ramach formujących się struktur społecznych, często zupełnie odmiennych od tych znanych z Europy, z drugiej jednak strony emigranci wciąż czuli silne związki z kulturą rosyjską, utrzymywali kontakty z osobami, które zdecydowały się na pozostanie w Rosji, oraz emigrantami (często również żydowskiego pochodzenia). Właśnie te relacje, utrwalone $w$ formie listów, pozwalają na poznanie złożoności zagadnienia i stanowią najbardziej interesujący z punktu widzenia badacza wątek zbioru.

Vladimir Khazan wskazuje we wstępie, że to zespół tych wielopoziomowych relacji stanowi główny problem zbioru:

Wielopłaszczyznowe relacje między europejskimi emigrantami rosyjskimi a Palestyna stanowią podstawę tego cyklu. Kwestia ta nigdy nie była przedmiotem odrębnego badania naukowego, zwłaszcza wyczerpującego i maksymalnie wszechstronnego. Z należytą ostrożnością należy podkreślić, że ten program badawczy, jego rozwój i rezultaty, mogą rzucić światło na wiele aspektów historii emigracji europejskiej i rosyjskiej, które wcześniej pozostawały niejasne, nieznane lub nierozstrzygnięte. Co nie mniej ważne, może on pomóc nam w wyjaśnieniu historii Erec Israel/państwa Izrael'.

Aby móc odpowiedzieć na te złożone zagadnienia, studium składa się z dwóch zasadniczych płaszczyzn: z jednej strony skupia się na losach diaspory w krajach europejskich, włączając

\footnotetext{
V. Khazan, Introduction to the Series, w: Russian Philosophy in Exile and Eretz-Israel, p.1, Nikolai Berdyaev and Yehoshua Shor: A Correspondence between Two Corners (1927-1946), red. V. Khazan, The Hebrew University of Jerusalem, Mount Scopus, Jerusalem 2019, s. 12. Tłumaczenie z angielskiego moje — P.t.
} 
w to analizę jej wpływu na losy poszczególnych jednostek, grup, organizacji i instytucji kulturalnych i społecznych w Izraelu, z drugiej strony przygląda się natomiast wielopłaszczyznowemu wpływowi diaspory na historię Erec Israel.

Lektura zbioru pozwala na dostrzeżenie dynamiki zmian układów panujących wewnątrz emigracji oraz na linii diasporaIzrael. Co oczywiste, w znacznej mierze wynika ona ze zmieniającej się sytuacji konkretnych kręgów emigrantów oraz szerszego tła społecznego i politycznego w poszczególnych państwach. Szczególne znaczenie odgrywa natomiast w przypadku Niemiec lat 30., które przed zwycięstwem Hitlera i nasileniem się nastrojów antysemickich były domem dla wielu rodzin Żydów uciekających z bolszewickiej Rosji.

Przywołanie historii konkretnych osób - często kilkakrotnie zmieniających miejsce pobytu przed finalnym udaniem się do Erec Israel, pozwala w niezwykły sposób zobrazować złożoność procesów i różnorodność kręgów emigracji żydowskiej lat 20. i 30. Redaktor tomów skupia się przy tym na różnorodnych metodach komunikacji oraz kontekstach, w tym również podróżach z jednej strony emigrantów żyjących w Europie do Izraela, jak i mieszkańców Palestyny do Europy. Pod tym względem zbiór stanowi kronikę wielopoziomowych relacji rozwijających się w trakcie dwudziestolecia międzywojennego, co pozwala na zobrazowanie wielu kontekstów budowania się żydowskiej i emigracyjnej świadomości:

\footnotetext{
W gruncie rzeczy to właśnie to wyzwanie - odkrycie duchowo-kulturowego potencjału żydowskiej Palestyny (,Ile mamy prawdziwej formy teatralnej i gdzie ona jest?") — leży u podstaw naszego projektu. Głównym sposobem na jego odkrycie jest zbadanie kontaktów mieszkańców Palestyny z różnymi enklawami artystycznymi i osobami należącymi do rosyjskiej diaspory w Europie ${ }^{2}$.
}

Pierwszy tom zbioru zawiera korespondencję pomiędzy Nikołajem Bierdiajewem - słynnym filozofem zmuszonym do emigracji (Rosję opuścił w 1922 roku na pokładzie tak zwanego statku filozofów, najpierw trafił do Berlina a następnie do Paryża, gdzie zmarł w 1948 roku) — a Jewsiejem Dawidowiczem Szorem (1891-1974) - historykiem filozofii, kulturologiem, tłumaczem, muzykiem i krytykiem sztuki, który w 1934 roku osiadł w Erec Israel i żył w niej aż do śmierci. Redaktor serii skupia się przy tym na kilku istotnych zagadnieniach: przede wszystkim kompleksowym przedstawieniu sylwetki i dokonań twórczych Bierdiajewa -

2 Tamże, s. 16. 
jednego z najważniejszych rosyjskich filozofów XX wieku, który w niezwykły sposób doświadczał traumy emigracji. Drugim celem jest bliższe przyjrzenie się dorobkowi Szora, archiwizowanemu obecnie w izraelskich instytucjach. Wyłania się z nich obraz niezwykle wszechstronnego naukowca, tłumacza, popularyzatora wiedzy, krytyka literackiego i nauczyciela muzyki.

Korespondencja pomiędzy Bierdiajewem i Szorem zwraca uwagę na "dziedzictwo rosyjskiej filozofii w starożytnej ziemi żydowskiej"3. Rzuca przy tym nowe światło na zjawisko syjonizmu oraz prądy syjonistyczne zarówno w Rosji, jak i w kręgach emigranckich. Jak pisze Khazan:

Można powiedzieć, że syjonizm płynął w żyłach Szora i wielu innych rosyjskich Żydów, którzy przeprowadzili się do Erec Israel. Jednak ich syjonizm był kształtowany nie przez klasyczną ideologię tego nurtu politycznego, ale przez rosyjską filozofię. Duchowa charakterystyka Szora jest świetnym przykładem paradoksalnego połączenia żydowskiej mentalności i cech charakterystycznych rosyjskiej inteligencji. Ta specyficzna mieszanka była produktem kulturowej symbiozy wewnątrz jego kraju4.

Część druga Around Lev Shestov's Visit to Eretz Israel in 1936, wydana w 2021 roku, skupia się na wizycie emigracyjnego filozofa Lwa Szestowa w Izraelu. Po raz kolejny więc obiektem analizy staje się życie i twórczość wielkiego rosyjskiego myśliciela, który w latach 20. był zmuszony do emigracji (Szestow umarł w Paryżu w 1938 roku, wcześniej przebywał natomiast m.in. w Genewie). W trakcie pobytu zatrzymał się w położonym w TelAwiwie domu swojej siostry Jelizawiety Izaakowny (po mężu Mandelberg). W Palestynie żyło także wielu przyjaciół i bliskich myśliciela.

Książka stanowi najbardziej rozbudowane studium podróży, która miała miejsce wiosną 1936 roku, oraz jej szerszego horyzontu - filozof planował ją już w połowie lat 20.

Podczas następnego okresu ponad 10 lat wciąż zbliżał się do osiągnięcia swojego celu, jednak za każdym razem realizacja marzeń była niemożliwa. Szestow nie był w stanie opłacić podróży do Palestyny, ponieważ taka wycieczka była dla niego zbyt droga. Palestyński związek pracy, który starał się zorganizować wizytę był siłą, z którą musiano się liczyć wewnątrz państwa, jednak jego stosunek wobec cyklu wykładów filozofa musiał być co najmniej ambiwalentny: w końcu te wykłady nie miały nic wspólnego z ówczesną sytuacją polityczną (w przeciwieństwie do wykładów Wiktora Czernowa, jednego z założycieli i naczelnych ideologów Rosyjskiej Socjalistycznej Partii Rewolucyjnej, który odwiedzał Erec Israel w pierwszej połowie 1935 roku

Tamże, s. 52.

Tamże. 
i spotkał się z entuzjastycznym powitaniem). Z założenia Szestow nie mógł liczyć na podobne przyjęcie przez palestyńskich robotników - sfera jego działań była zbyt odległa od zainteresowań szerokich mas. Jego wykłady przemawiały jedynie do kręgu elit intelektualnych, których przedstawicieli można było wyliczyć w Palestynie w tuzinach ${ }^{5}$.

Już analiza tych dwóch materiałów zbiorowych - ujętych odpowiednio w pierwszej i drugiej części zbioru - wskazuje więc $z$ jednej strony na zespół podobieństw, a $z$ drugiej różnic budujących ówczesną rzeczywistość kręgów emigracyjnych oraz złożoność procesów zachodzących w samym, wciąż tworzącym się, społeczeństwie przyszłego państwa Izrael. Nawet Hebrajski Uniwersytet $w$ Jerozolimie, a więc największy ośrodek naukowy i intelektualny w Palestynie tamtych czasów — był raczej niechętny wobec wizyty znanego już wówczas i cenionego na całym świecie filozofa. Było to także związane z kwestiami czysto finansowymi: jednostka naukowa pozyskująca środki od organów Mandatu brytyjskiego nie mogła sobie pozwolić na zaproszenie myśliciela, nie wpływał na to nawet fakt, że rektor uczelni, Hugo Samuel Bergmann, doktor filozofii, zdawał sobie sprawę ze znaczenia Szestowa i jego pozycji w świecie ówczesnej nauki. Co więcej, Bergmann nie był także obecny w trakcie jakiegokolwiek wykładu Szestowa w Palestynie, kiedy wyjazd udało się już zorganizować.

Różnicę pomiędzy "wiedzą popularną" i "wiedzą elitarną" podkreśla również wzmianka na temat wykładów Szestowa w TelAwiwskiej gazecie "Hayarden" - jerozolimskiemu uniwersytetowi zarzucano wręcz niedocenianie faktu organizacji wykładów przez tak prominentnego i znanego w całym świecie myśliciela:

Szeroko znany rosyjski filozof Lew Szestow, którego prawdziwe żydowskie nazwisko to Szwartsmann, jest zmuszony do zmagania się z życiem emigranta w Paryżu. Jest wykładowcą Sorbony, obecnie Uniwersytet na górze Scopus [Hebrajski Uniwersytet w Jerozolimie] może docenić jego wartość... Mówi się, że został zawiązany specjalny komitet w Tel-Awiwie, którego zadaniem jest organizacja przybycia Szestowa do Erec Israel, gdzie zamierza dawać wykłady przed dużymi audytoriami ${ }^{6}$.

Z jednej strony wykłady Szestowa nie były więc zbyt atrakcyjne z punktu widzenia przeciętnego odbiorcy, z drugiej jednak sama wizyta była możliwa wyłącznie dzięki olbrzymiemu wysiłkowi

5 V. Khazan, Introduction, w: "The Marvelous Land of Palestine". Around Lev Shestov's Visit to Eretz Israel in 1936, Russian Philosophy in Exile and Eretz-Israel, cz. 2.1, red. V. Khazan, The Hebrew University of Jerusalem, Mount Scopus 2021, Jerusalem, s. 20.

6 Cyt. za: V. Khazan, Introduction, w: "The Marvelous Land of Palestine”. Around Lev Shestov's Visit to Eretz Israel in $1936 . . .$, s. 22. 
wielu ludzi, głównie reprezentantów elit, którzy dostrzegali wagę tego wydarzenia dla życia kulturalnego, naukowego i społecznego szerokich mas narodu wypracowującego dopiero swoją tożsamość w zupełnie nowych warunkach. Ten był jednocześnie w znacznej mierze uzależniony od indywidualnego podłoża kulturowego i intelektualnego jego poszczególnych reprezentantów (co znamienne - również emigrantów, przy tym często napływających w ramach trzeciej i czwartej alii).

Złożoność tych procesów i interpretacji dostrzegał również sam Szestow, który w liście do Lwa Mandelberga z 11 czerwca 1926 roku pisał:

W ogóle dostrzegam, że osoby, od których zależy i cykl wykładów, i wszystko inne, niezbyt pragną widzieć mnie w Palestynie. Ani związek pisarzy, ani organizacje robotników, o których pisałeś, ani poszczególni pisarze nie zrobili do tej pory nic, aby skłonić tutejszych syjonistów do podjęcia jakichkolwiek kroków?

Zebrane przez Khazana i Vladimira Janzena materiały źródłowe mieszczące się w dwóch tomach: artykuły, relacje z wykładów, ilustracje i listy, w tym bogaty zbiór korespondencji pomiędzy Lwem Szestowem a Martinem Buberem, pozwalają na kompleksowe przyjrzenie się tej wizycie nie tylko w odniesieniu intelektualnym, ale również społecznym i praktycznym. Okazuje się, że interesująca i wartościowa dla współczesnych badaczy jest nie tylko sama tematyka wykładów i analiza zaprezentowanych przez Szestowa tez, ale również kwestie organizacji tak ważnego dla całej społeczności żydowskiej wydarzenia.

Seria Eretz-Israel and the Russian Émigrés in Europe: Contacts, Connections, Communications, Interactions (1919-1939) jest bez wątpienia przełomowym opracowaniem przydatnym nie tylko z punktu widzenia badaczy ruchów syjonistycznych i kwestii odtwarzania kulturyżydowskiej w granicach Erec Israel, ale również osób zainteresowanych losami emigrantów z Rosji bolszewickiej w okresie niemal całego dwudziestolecia międzywojennego. Dzięki sumiennemu opracowaniu i zaprezentowaniu (często po raz pierwszy) wartościowych materiałów źródłowych to wyjątkowa pozycja zasługująca na uwagę zarówno naukowców i studentów, jak i zdecydowanie szerszego grona odbiorców poszukujących bezpośredniego dostępu do tekstów, które w znacznej mierze decydowały o kształcie życia kulturalnego i intelektualnego zarówno ówczesnej Palestyny, jak i Europy i świata.

Tamże, s. 23. Tłum. z rosyjskiego — P.t. 